\title{
Values connecting Societies and Water Systems
}

\author{
Jacko van Ast, Jan Jaap Bouma, Mansee Bal \\ Department of Public Administration, Faculty of Social Sciences \\ Erasmus University, Rotterdam, The Netherlands
}

\section{Introduction}

Water systems such as rivers and lakes have many important values for ecosystems and human societies. Both economical, social-ecological, cultural and political values are met by the water systems, connecting different activities in human society and ecosystems. Water systems with low water quality serve different values than healthy water systems and have huge impact on the society. For example, for drinking water, biodiversity or recreational open space, a healthy water system is crucial.

The values of the water systems are interlinked. The interlinking and overlapping values of the water systems at the spatial and temporal scales have determined a connective capacity in the water governance, be it the coordination between the values or the competition between the values and its linked governance approach. The challenge is values of water systems change with the change in the societal development and consequently influence the water governance approach. A reverse process is also evident. Unfortunately, today water systems in many cities have slowly reduced in their total value for society. The revival of the water systems such as river and lakes is thus seem to be urgent in order to enhance the values generated by these systems for the society.

The concept of connective capacity can be applied to the values generated by water systems, where these values bring activities, and on a higher level the ecological and social systems, together. With the historical development of changing values of water systems this can be illustrated. Main questions are what we can learn from the connecting capacity of values and if these values play a role in (inter)connecting societies and water systems. The chapter provides analyses of the changing values in water management in The Netherlands and in India, illustrated with examples of urban lake systems. It discusses how values of the water systems (inter)connect societies and water systems, and in turn influence the water governance and vice versa. The findings are based on literature review and broad stakeholder analysis conducted from repeated field visits to the lakes sites in Tilburg and Ahmedabad from 2005-2010. The field visits included semi-structured and open ended interviews with the stakeholders, backed by document analysis.

\section{Dynamics in Values and Water Governance}

\subsection{Values of ecosystems}

The multiple objective approaches in current water management are derived from the different values of the water systems. The term 'value' is broad and multidisciplinary and has different interpretations in different disciplines. In the total economic value (TEV) framework Pearce and Moran (1994) divide values in instrumental value (or use value) and intrinsic or passive (or non use) value. The instrumental value is subdivided into direct use value, indirect use value and option value; and the intrinsic 
value is subdivided into existence value and bequest value. In case of rivers and lakes, ground water recharge, swimming and washing are the direct use values. Experiencing the water, the landscape, the fauna and the flora are examples of the indirect use value, while planning of recreation or real estate development belongs to the option value of natural water systems. The non use values are slightly more problematic in definition and estimation. Conserving it for its very being/identity as an asset is referred as the existence value, and conserving the lake for future generations is the bequest value.

The use and non use values combined can be considered in alignment to the definition of sustainability by the World Commission on Environment and Development, development that meets the needs of the present without compromising the ability of future generations to meet their own needs (WCED, 1987). The use values and nonuse values can be categorised depending in which domain the use and non-use values are referred to and related to, such as ecological values, economic values, social values, cultural values and political values. The ecosystem values encompass all the goods and services generated from the ecosystem of water. The 'value' in this chapter refers to the array of functions performed by the water systems from its source of generation to the consumption and the waste water generation. It encompasses all kinds of values discussed in the TEV. The choice of values by the society at a certain time period is usually reflected in the governance of the specific water systems such as lakes.

\subsection{Water Management}

Water management and water governance is defined in different ways (Teclaff, 1996; Biswas, 2004; Biswas, 2008; Hooper, 2005). The Dublin Conference on Water and the Environment uses "Integrated Water Resource Management", based on a participatory approach, safeguarding availability and vulnerability of water and taking into account affordability and equity criteria (ICWE, 1992). The concept was elaborated in the United Nations Conference on Environment and Development in Rio de Janeiro (UNCED, 1992).

The modern multiple objective approach is known as "adaptive management" where water managers continually adjust their actions in response to monitoring data and insights that informs about changes in the characteristics of a water system, its catchment area, economic conditions and social preferences with respect to the values a water system is expected to fulfil. Water managers no longer dominate the decisionmaking process related to managing the flow of the river, its quantities and its quality. They are now more open for support from stakeholders within the process of participation (Van Ast, 2000). In this respect, currently the concept of water governance is used. Taking the stakeholders into account means that the costs and benefits of the different values of water systems are to be balanced. In its turn this leads to a request for insight into the processes of valuation and its institutionalization. Examples are Cost Benefit Analysis, Multi Criteria Analysis, Co-valuation (van Schie and Bouma, 2008; Schuijt, 2003; Bouma, et al., 2008; van der Veeren and van Cleef, 2008). In contrast to the traditional water management approach, it advocates the need for coordination, integration and synchronization of values, interests, responsibilities and tasks within water management and governance (Biswas 2008). 


\subsection{The Involvement of Values in Governance}

The way values play a role is for a large part dependent on the way government organises the use of the goods and services of the water system by different stakeholders. To some extent it is coordinated by market mechanisms based on financial (monetary) value (maximization of profits) as the value paradigm. The role of the market mechanism however is subject to an ongoing debate. Stakeholders compete for accessibility to the water systems. In this respect, different values and the chains of stakeholders (like dinking water producers, distributors and consumers) that make use of them, may be organized in different ways under different market conditions. The overall coordination of the relevant value chains within one state and between states connected to a water system is regarded as problematic. Different countries have often different traditions and sets of values associated with water systems. They also vary in the way how property right systems are embedded in legal and institutional environments. Different value chains may be characterized by their own governance model or framework. In regional and urban planning many values are involved. In this context historical, cultural, recreational and other economic values may overrule or consolidate the ecological values of a water system. However, the coordination of a water system is not overarching all other coordination systems that in the end of the day explain the quality of a water system especially in an urbanized region. It becomes even more complex because over time different coordination systems responsible for the quality of a water system or parts of it, change.

An innovative approach of 'virtual water' or 'water footprint analysis' may allow water to be channelled towards those value chains and those units within these chains that provide the highest value (Hoekstra, 2008). However, it is still a new concept and unclear how this valuation process should be organized and woven into practical governance models or frameworks and which values are to be included in the value concept that is relevant in the governance of a water system.

General notions on the role of institutions in the coordination mechanisms in infrastructures of Williamson $(1979 ; 1998)$ or North $(1990))$ consider the impacts of relevant mechanisms of processes of institutionalization (DiMagio and Powell, 1983). It is still fuzzy if and how current and future adaptive strategies for governing water systems embed the values that are reflected in the theoretical framework and acknowledge the performance measures (outcomes) policy makers aim for (Valkering \& Offermans, 2008). The impacts of Climate Change on water systems and their values introduced a permanent degree of uncertainties on the final effects on societies. In the current urban water governance approaches the challenge in formulating adaptive water strategies is how to deal with potential conflicting value-concepts of the stakeholders and the costs and benefits.

The governance of water systems depends on local and contextual variables. Some of these variables are the involved traditional and economic values that are at stake. Other variables are related to the institutional arrangements that embed the specific values into the management of water systems. Sometimes this may result into the dominance of some economic sectors that have the ownership and consequently use the specific water system according to their preferences. Local tendencies towards or away from integrated and sustainable water management approaches are key 
characteristics of water governance. These contextual variables are discussed in the following studies of Dutch and Indian water management and illustrated by the Tilburg and Ahmedabad settings as they are identified by the stakeholders.

\section{Water Governance in the Netherlands}

\subsection{Values and Paradigms}

The history of Dutch water management shows a long development of change in values and governance (Van Ast, 1999; Van der Brugge \& Rotmans, 2010). The early intervention with water in the Netherlands was primarily associated with the fear of flooding and later with fear of diseases. Many efforts were made to fight the water and its health risks. At first, mounds were formed; small hills of a few meters, where the water could not reach the houses. Later, the construction of dikes became the major strategy to keep the water away from the land. After some centuries of experience with dikes and drainage ditches, the combination with windmill technology created a very successful strategy against flooding. It appeared that it was even possible to create land from the sea, by making a ring of dikes and consequently pump the water out (Dubbelman, 1999). The efforts result from the dominating values of the times, when productive land was increasingly important. The population increased and agriculture needed more space to feed all inhabitants. The other fight came with awareness of the risks of polluted water and the value of clean drinking water for human health. It resulted in physically dividing the contaminated water from the people. In no time, the water systems obtained religious value in the society.

Looking at the economic value of water, fishing had the earliest focus. The existence of water bodies ensured the availability of food for people. With modernisation, due to over harvesting and pollution the fish stocks collapsed which changed the food habits of the people. From Medieval times, water as a mode for transportation gained importance in river systems. It resulted in a large water infrastructure connecting cities and villages through existing natural lakes and rivers. Due to its geographical position, the Netherlands always enjoyed the connective capacity of rivers for transport.

The field of interest of the water manager has followed the value perception in society and consequently broadened considerably with time. During the 20th century, the specific water sector policy made many new values explicit, like the recreational, ecological and aesthetical values. The environmental value became significant due to the high pollution loads in the water. Conflicts with upcoming values like nature and ecology and the awareness that the use of water as waste collector is unavoidable became apparent. It also brought the realisation that the physical division of water does not avoid all the health risks. With new technology cleaning of water systems became possible and many values depending on clean water turned realistic. This is the time of the paradigm shift in water governance from "fighting the (dirty) water" towards "living with (clean) water".

When in the mid eighties the awareness increased that sector optimization created major drawbacks, the concept of integrated water management took off at the Ministry of water management and infrastructure (1985; Saeijs, 1995). It is based on a water systems approach, transcending environmental compartments. The integration 
not only refers to surface water and groundwater or to water quality and water quantity; includes the various uses and the connected policy. In this phase, significant changes in thinking emerged in the society and the water managers. First, the change was from the protection of humans against the water to the protection of the water against human. Perhaps the most important insight is that ecology was considered the basis of managing water, i.e. the ecosystem approach in water management (Allen et al, 1992).

In the nineties of last century, a further broadening of thinking occurred with the implementation of the concept of sustainable development WCED (1987) and the Water Framework Directive (EU, 2000). Dutch water governance intensified the approach towards nature protection and environmental regulation. It lead to the concepts like dynamic or adaptive water management (Geldof, 1994), total water management (Van Rooy et al, 1997), participatory and interactive water management (Van Ast, 1999). A large system of institutions evolved in governing the water systems with different actors, on different levels and scale belonging to various policy fields. In general, the State (ministry) is responsible for the main lakes, rivers and canals; while a specific layer of democratic water boards manages the regional water infrastructure. Ministries, provinces, regional water boards and municipalities own the water systems. Only in rare cases, smaller physical water bodies that do not have a function in the main water infrastructure are sold to the private sector, but the State always sets conditions for their maintenance. Privatization in the drinking water has not taken place. Traditionally, the role of market mechanisms in the water sector are low (EUROmarket, 2003) except the exploitation for recreational purposes. Waterworks and the maintenance of water systems have arrangements. Some rely on local taxation schemes (water board taxation) that are designed as a logical consequence of a relatively restricted role of market mechanism with its dominance of market priced values. Others, especially those works that are of safety importance are financed out of collective national funds.

Despite the trend to connect the different values and related expectations, the optimization of the realized value is not yet a proven case. In summary, it can be observed that the surface water changed from a primarily negative value due to flood and health risks to a positive value in terms of ecology and aesthetics.

\subsection{Case: Changing values of small Lakes in Tilburg}

In the following, an illustration of the changing values is given by small lakes, situated in the city of Tilburg. They have fulfilled many different values for ages and spatial planning reveals that safeguarding of the primary value of recreation is the key. The integration of the value of water systems into spatial planning initiatives started from the economic perspective. Possible impacts of water streams are controlled to maintain the water quality and quantity for the recreation. High water quality standards go along with the swimming water standards. It is observed that the conditions for the recreational swimming function even underpin the need for complying with the legal ecological standards. In recent times, the recreational value is challenged by urbanization and became less important as a result of increased supply of competing recreational arrangements. This is visible particularly when:

- water quality and quantity standards are to be met; 
- the number of visitors and the entrance fee they pay can outweigh the costs of maintenance and opportunity costs of not using the area for further urbanization.

At this stage all the stakeholders with their own values are considered in the benefitcost assessments takes place. It is questionable to what extent such decision-making processes are open to those stakeholders with unknown values and stakes. It is the ongoing challenge to keep the decision making process open to let new stakeholders into it as they may be innovators in the field of managing urban lakes.

Water systems may connect different knowledge suppliers with old and new users of this knowledge that may be embedded in completely other fields than of managing water systems. For example, to safeguard the recreational value of the lake, the private company who holds the concession, introduced an innovative finger scan technique that is also applied in many economic sectors with a need for such kinds of security and entrance control systems.

This case shows that the decision on water quantity and water quality characteristics of a lake is spatial and temporal specific. Most recent developments demonstrate a stronger dominance of the market mechanism. A lake in Tilburg now offers a natural swimming surrounding with recreational facilities. The local governments believe that the natural swimming facility and the future existence of the lake will depend on the economic feasibility of the recreational facilities offered at this lake.

\subsection{Stages of Water Governance in the Netherlands}

Historically, abundance of water in the Netherlands made safety as essential value, since the low-lands were very vulnerable to flooding from the rivers and from the sea (Van Ast, 1999). Later, values like safety oriented water quantity management lead to land reclaiming projects, besides the improvement of inland navigation.

In the twentieth century, an acceleration of the use of functions of water systems was realised. In this stage sectoral water management, like agriculture, industry, drinking water etc., all called for specific attention from the water managers. Even the quality of water formally got its sectoral place in 1970, when a specific law was published, followed by an explosion of water quality policy documents. The State is the service provider and community, agriculture and industries are the users. Water systems had to follow the social systems, i.e. governmental planning. In the eighties of the twentieth century, the sectoral approach reached its limits. It became necessary to make decisions about the water system as a whole. This urged for integrated water management, aiming at the ability of the total water system to supply the optimum of the many demanding sectors.

In the beginning of the $21^{\text {st }}$ century a paradigmatic shift, or transition (Van der Brugge \& Rotmans, 2010) is taking place. Terms like resilience, participation, adaptation, and transition management refer to the practice of sustainable water management, generally characterized as "adaptive water management". In this approach the water managers adapt to the values the water system provides. If values change, their management will change. Nowadays, the concern (in itself a value) that has been given to the climate change issues plays an important role. Again the development is directed to more complexity, where land planning increasingly follows the natural 
systems, not in the last place in order to avoid additional costs. But more and more, social systems (and planning) follow the water systems.

The Dutch history of water governance consists of three main stages, in which in every new historical phase, new values emerged. The dominance of specific values of water systems can be identified how and what extent these values are safeguarded in legislation and other policy instruments. Table 1 provides insights in the relative values identified. They are embedded into the policy design of the successive generations of EU water directives; which directly shape the Dutch water governance approach (Euromarket, 2003). It can be argued that all values are fully embedded into current governmental policy approaches. However, the overview does not reflect the market prices and the role of market mechanism

\begin{tabular}{|l|l|l|l|}
\hline & \multicolumn{2}{l|}{$\begin{array}{l}\text { Importance: } \\
* \text { little, ** significant, **high }\end{array}$} \\
\hline $\begin{array}{l}\text { RELATIVE VALUE } \\
\text { (importance related to other values) }\end{array}$ & $\begin{array}{l}\text { Historical } \\
\text { (+- before 1900) }\end{array}$ & $\begin{array}{l}\text { Modern } \\
(+-1900-2000)\end{array}$ & $\begin{array}{l}\text { Recent } \\
\text { (+- after 2000) }\end{array}$ \\
\hline Religious/spiritual & & & \\
\hline Drinking water & $* *$ & $* *$ & $* *$ \\
\hline Fish production & & $* *$ & $* *$ \\
\hline Transportation by ship & $* *$ & $* *$ & $* *$ \\
\hline Sand and clay & & $*$ & $*$ \\
\hline Transportation by pipes & & $*$ & $*$ \\
\hline Recreation & & $*$ & $* * *$ \\
\hline Cooling water & & $*$ & $* *$ \\
\hline Electricity production & & $* *$ & $* *$ \\
\hline Ecology & & $*$ & $* *$ \\
\hline Attractive for housing (aesthetics) & & $* *$ & $* * *$ \\
\hline
\end{tabular}

Table 1. Changes in value perception in the Netherlands

\section{Water Governance in India}

\subsection{Values and Paradigms}

From the early civilization, environmental values linked to the water systems were veiled behind the socio-economic and cultural values that are linked to the direct use value. Since antiquity in India, water enjoyed a respectable and unique status amongst all the natural resources. Like air, wind and sunlight, water was considered to be an unlimited resource in ancient India. The existence value and the bequest value did not appear at the centre of the water management; however, it was embedded in the traditional community water management as a fundamental factor.

The first reference to the hydrological cycle in the world came from the Chandogya (Agarwal et al., 2001). Chandogya is part of one of the principle philosophical texts of Hindu religion called the Upanishads. The main agenda of water management was to meet the demand of water for domestic and irrigation purposes and for the protection against floods and droughts (Bansil, 1991). Since agriculture became part of civilization, land management interlinked with water management was in the forefront of water system governance. (Bal, 1999). With water as a deciding factor for growth and prosperity, indigenous practices of water conservation, water harvesting, and transportation of water from remote areas emerged. These practices were given shades 
of ritualistic overtones and were woven into the religious and social-cultural habits resulting into a widespread practice at community level.

An important aspect of socio-cultural values is that rivers and lakes are considered to be sacred till date. Every religious and ceremonial occasion have some association with the rivers and lakes (Agarwal and Narain, 2001). Rivers/lakes are referred by the names of a female goddess, such as the five main holy rivers of the country are called by Ganga, Jamuna, Godavari, Narmada and Kaveri. It is believed that a dip in any of these five holy rivers washes ones sins away. The sacredness is testified by the fact that even today, thousands of pilgrims perform the holy pilgrimage of Circumbulation (called Parikrama) to these rivers every year. Other rivers and lakes enjoy a similar holy status in India. Traditional fairs like Kumbh Mela at the banks of river Ganges and Pushkar Mela at Pushkar Lake are still very popular across the country and even got attention internationally.

In earlier days, the social processes followed the water system. The values of the water systems were directly linked to the people of the community and the management of rivers/ lakes was inherently integrated in the community life. Although the property rights of rivers and lakes remained with the government; formal and informal rules were usually crafted by the community for water usage, maintenance, sanctions etc. (Ostrom, 1990). The hydrological cycle, the water balance principles and the community water management systems were known to the community through wisdom and experience passed from one generation to the other (Bansil, 1991).

The economic values such as fishing, transportation and irrigation were always embedded with other values. Pilgrimage to sacred rivers and lakes for socio-cultural events involved many economic activities such as religious fairs, trade fairs, animal fairs and even bride/groom fairs. Popular traditional events are still organised in the honour of rivers and lakes and held at their banks. The economic value of water increased by the mid twentieth century with tourism linked to recreation, ecotourism and water sports. In addition, the use of water in hydropower, industry and municipal consumption gained prominence. Technological developments such as dams linked to rivers and lakes for energy generation and irrigation are considered to be the key economic drivers of the society. Water management with scientific and sophisticated tools aimed at optimal utilisation and management of the water systems and to make the development more complimentary to the environment and economy became usual.

Water became significant concern by the end of twentieth century in terms of lack of availability and accessibility, because it started affecting economic growth and even the balance of human life. The state of rivers and lakes, the community and the water governance changed. Rivers and lakes became a politically contested resource at city level, state level, national level and even international level. Reclamations of land from the rivers and lakes for urban development activity became common at city level. Urban development and planning began to dominate over the existence of the water systems (Bal, 1999). Governing surface and ground water separately became a challenge adding more complexity with water quantity and quality management (World Bank, 1998). The growing demand and competition between municipal consumption and industry due to the rapid urbanization; the uncontrolled access to surface water and groundwater and the lack of proper institutional arrangements led to 
pollution and degradation of surface water and ground water sources. The water exploitation indiscriminately affected the health of rivers and lakes; and droughts and floods became common in many cities. The river and lake beds turned into large cesspools and became the recipients of industrial and domestic wastes, generated from the cities. In addition, land encroachments and squatting by the residents, industries and sometimes even by the state organisations affected the rivers and lakes systems.

The growing disagreement on sectoral water management led to the integrated water resource management (IWRM). IWRM as a process to promote coordinated development and management of water, in order to maximize economic and social welfare in an equitable manner, without compromising the sustainability of vital ecosystems (Bansil,1991). Although there was an overtone of socio-economic values in IWRM in the form of peoples' participation, employment generation; the mindset that water is a government's business prevailed in the society. This was the time when the slogan of 'access to water was considered to be a fundamental right of every citizen'. The state being the authority was obliged to take care of 'water as a good', with the citizens as end users. Narain (2000) advocated institutional reforms in India's water governance through: securing greater coordination and integration within the water management organizations; restructuring water bureaucracies as inter-disciplinary, financially autonomous organizations; and defining water rights and dual accountability between user groups and the bureaucracy.

In the last decade, sustainability of lakes and rivers became high in the water governance agenda because of the growing threat to the existence of rivers and lake. Water gained more focus on environmental grounds when the concepts of climate change and global warming came in the forefront of global environmental agendas. The National Water Policy of 2002 puts emphasis on integrated water resource development and management for optimal and sustainable utilization of available surface and ground water resources; creation of sound information systems; use of traditional methods of water conservation and non-conventional methods for water utilization and demand management; and to have a synergy between the government and non-governmental organisation for water conservation and utilization (MoWR, 2002). The year 2003 declared as the 'International Year of Freshwater' by the United Nations made water the subject of most environmental and developmental discourses. National and international water initiatives became very active in India, such as the formation of the National Lake Conservation Plan (NLCP) in 2003; the promotion of River Basin Organisations (RBO) in the line of integrated river basin management (IRBM similar approach as IWRM); and many wetlands were declared as Ramsar sites for conservation. The legal institutions and community based organizations are also more active over environmental concerns of water (Reddy and Char, 2006).

The concept of sustainable water management (SWM) is now common in the policy and research domain in India. The catch is who uses it and what values are attached to it. The use-value in terms of social-economic values are driving however, the bequest value and intrinsic value in terms of ecological values are slowly gaining momentum. Sustainability of rivers and lakes are linked to the sustainability of cities. It is also the time of bringing people back into the issue of water governance. Water Users Association (WUA) formations for managing canals, lakes and ponds, portion of rivers, irrigation systems are considered an efficient way to get better outputs in water management (Narain, 2000). The WUA became effective and functioning in many 
rural areas but still face problems to take-off in urban areas. The urban lifestyle and occupation keeps urban people away from direct interaction to the water systems and rivers/lakes are perceived as places of recreation; and water as a 'service' for which people pay tax or user charges (Bal, 2006).

The several values involved in the water governance in India are reflected in the several sectors and institutions involved in governing the river and lake systems. Reddy and Char (2006) present a comprehensive list of institutions linked to water governance and show concerns over the fragmentation of responsibilities and coordination amongst the organisations and policy implementations.

One of the prominent ways in which water governance is reflected in the society is in spatial development. Plans and projects for river/lake regenerations and redevelopments; rehabilitation of slums encroaching the river/lake beds; waste water treatment plans; and rain water harvesting are exceedingly seen as important in addition to the modern water quantity and quality management (Bal, 2006). Since developing new sources of water is costly; the logic of re-using the waste water generated from municipal consumption and industry also rose as new domain in the water governance. Waste water is now realised to be an alternative source of water. Such initiatives are underway within the Jawaharlal Nehru National Urban Renewal Mission, JnNURM (AMC and AUDA, 2005); under this scheme river/lakes are addressed through the infrastructure (waste water and/or storm water) development. The privatization and public-private partnership (PPP) initially took off with lot of promises since, international organizations such as World Bank, International Monetary Funds, Asian Development Bank promoted private sector-led growth in water works and services. PPP was promoted as vehicle to achieve the required growth in most infrastructures, including the water sector. Soon serious criticisms and disapproval rose from the civil society groups and experts regarding the priorities and strategies of the private sectors. PPP's further crumpled with the global recession when government finances were used to bail out many PPP projects. However, PPP's self probably will not disappear anymore, but their nature may change over time (Dwivedi, 2010).

\subsection{Case: Revival of Lakes in Ahmedabad city}

An illustration is given with some urban lakes in India. Just like many other villages in the earlier days, habitation in the region of Ahmedabad was strategically located at the edge of lakes and ponds. The lakes and ponds of Ahmedabad served several needs of rural life such as impounding the surplus of rain water, recharging the ground water reservoirs and feeding the wells, providing irrigation, supplying drinking water for human beings and cattle, providing places for bathing, washing, cultivation of water demanding produces, and a number of other functions. The governance of the lakes and ponds was therefore directly in the hands of village people. In the mid twentieth century, when the villages started getting engulfed in Ahmedabad's urban development, the functions of the lakes and ponds slowly changed. They became recipient of human and waste squatting. This was the phase of neglecting lakes and ponds in the city. The governing responsibility was under the national government, to who control and management was a farfetched work. At the same time, the local government was reluctant to go through the bureaucratic process to take over its development. Moreover, the community was by far the least interested in 
development, since the urban occupation and life style had no direct association with the lakes. However, in the last one decade, many lakes in Ahmedabad are revitalized for mainly city's infrastructure functions such as, storm water collections points for the storm water drainage system of the city, for recreational development, and for creation of real estate property in the form of land reclamation from the lake area (AMC and AUDA, 2005). The quality and quantity of the water in the lakes was less priority to the agenda of the development of the area. The property prices of the surrounding areas of the lakes that are developed rose very high. The governance is in the hands of local government, which is trying to reach partnerships with both private sectors and community based organisations.

\subsection{Stages of Water Governance in India}

Learning from what was described above, it appears that in historical India, the human health value related to water and food demands is reflected in domestic use, irrigation, safety from flood and drought protection. They were given shades of rituals and are linked to socio-cultural values. Ecological values were the underpinnings of the sociocultural values. Spatial development followed the existing rivers, lakes and other water bodies. State owned water was usually managed by the community. Social systems followed the water system.

In the $20^{\text {th }}$ Century, apart from the traditional economic values, benefits for larger developments at the core such as large and small dams for water reservoirs, energy generation, municipal and industrial consumption. Spatial development manipulated the existence of rivers and lakes and other water bodies that were State owned. State is seen as service provider, while community and industries are the users. Water systems follow the social systems.

Recently, periodical risks and consequences of degradation of water resources brought ecological and sustainability values high on the water governance agenda. Economicsocio-cultural values are considered necessary for ecological sustainability. Political value is considered prime in the aversion of the degraded state of water resources. State owned waters are managed increasingly in partnerships, with participation of community and NGOs. Integrated water management and sustainable water management are the main conceptualisations of the attempt to find balance between the social systems and water systems.

A kaleidoscopic overview of the value of water and water governance focusing on the river and lakes in India, which is presented above, is represented in the table 2:

\begin{tabular}{|l|l|l|l|}
\hline & \multicolumn{3}{|l|}{$\begin{array}{l}\text { Importance: } \\
* \text { little, ** significant, ***high }\end{array}$} \\
\hline $\begin{array}{l}\text { RELATIVE VALUE } \\
\text { (importance related to other values) }\end{array}$ & $\begin{array}{l}\text { Historical } \\
(+- \text { before 1950) }\end{array}$ & $\begin{array}{l}\text { Modern } \\
(+-1950-2000)\end{array}$ & $\begin{array}{l}\text { Recent } \\
(+- \text { after 2000) }\end{array}$ \\
\hline Religious/spiritual & $* * *$ & $* *$ & $* *$ \\
\hline Drinking water & $* * *$ & $* *$ & $*$ \\
\hline Fish production & $* * *$ & $* *$ & $*$ \\
\hline Transportation by ship & $* * *$ & $* *$ & $*$ \\
\hline Transportation by pipes & $*$ & $* *$ & $* * *$ \\
\hline Sand and clay & $*$ & $* *$ & $* * *$ \\
\hline Recreation & $* *$ & $* *$ & $* * *$ \\
\hline Cooling water & & & \\
\hline
\end{tabular}




\begin{tabular}{|l|l|l|l|}
\hline Electricity production & $*$ & $* *$ & $* * *$ \\
\hline Ecology & $* * *$ & $*$ & $* *$ \\
\hline Attractiveness for housing (aesthetics) & $* *$ & $* *$ & $* * *$ \\
\hline
\end{tabular}

Table 2. Changes in value perception in India

Large similarities between the development in domination values in India and the Netherlands can be observed. After basically life threatening values, during modernisation the economic values came into the picture, only recently followed by non use values.

\section{Discussion and Recommendations}

Over centuries there has been a strong relation between the value of water systems, like rivers and lakes, and the way these water systems are governed. Several values are associated with rivers and lakes, such as socio-cultural values, economic values, ecological values and environmental values. Values connect individuals, empower stakeholders and frame the water governance in a more comprehensive manner than before. Multiple sectors dealing with water governance is an outcome of the demand for different values by the society and consequently the water managers. From the examples it is reflected how the expected and realized values of lake systems result from the functions of the water system and the people of the society who bring in and have knowledge to manage water systems accordingly. Connecting values and the knowledge brought into the management scope have enlarged the possibilities for multi-functionality of the system and have helped in maximizing the total value of the water system.

Societies have exploited water systems in a way that they have reached their ecological limits. The governance emphasis tends to co-evolution between ecological and economic values. In a transition towards sustainability a trend is observed to ground human use on the limits of the natural water system, leading to practices like adaptation, participation and strengthening of resilience. Table 3 presents the change of values and the water governance approach over time.

$\begin{array}{ll}\text { Phase } & \text { Concept } \\ \text { historical times } & \text { - flood control (wet areas) drinking water } \\ & \text { supply (dry areas) } \\ \text { modernisation } & - \text { water quantity management } \\ & - \text { sectoral water management } \\ \text { recent times } & \text { - integrated water management } \\ & - \text { sustainable water management adaptive } \\ & \text { water management }\end{array}$

Table 3. Developments in the concept of water management

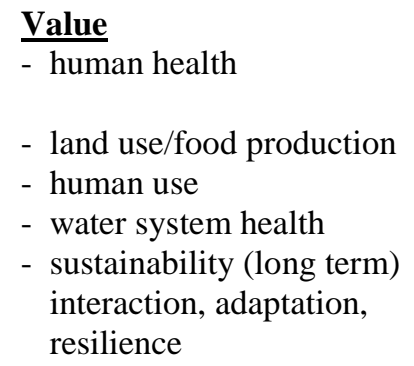

In general, the differences between the governance systems in The Netherlands and in the Indian society are large. Some differences in the governance of water systems appear to be temporal, corresponding with some national or local conditions that will disappear in the long run as a result of overarching trends reflecting on-going modernisation processes. In this respect, similarities in water management between Netherlands and India are likely to increase. Considering the transition, further 
research could identify the values that connect or compete with each other over time and space. A scheme that could give some guidance is presented in Table 4:

\begin{tabular}{|c|c|}
\hline FROM traditional water management & TO Modern water management \\
\hline Water as an 'enemy' & Water as a 'friend' \\
\hline - ' 'fighting against water' & - $\quad$ 'living with water' \\
\hline - $\quad$ Sectoral water management & Integrated water system management \\
\hline $\begin{array}{ll}- & \text { Effective and efficient }\end{array}$ & Sustainable: long term responsibility \\
\hline - $\quad$ Supply Management & Demand Management \\
\hline Water systems follow social processes & - $\quad$ Social processes follow water systems \\
\hline Water follows spatial development & - $\quad$ Spatial development follows water \\
\hline $\begin{array}{ll}\text { - } & \text { Technocratic: } \\
\text { - } & \text { build and maintain }\end{array}$ & $\begin{array}{ll}- & \text { Ecosystem based: } \\
\text { - } & \text { support resilience and self-regulation }\end{array}$ \\
\hline - National & - $\quad$ International en regional \\
\hline $\begin{array}{ll}\text { - } & \text { Government lead water management } \\
\text { - } & \text { 'Command and control' water policy } \\
\end{array}$ & $\begin{array}{ll}- & \text { Participative water management } \\
- & \text { Interactive water management } \\
\end{array}$ \\
\hline
\end{tabular}

Table 4. Changes in water management

These changes are the outcome of which values are attributed to water systems. 'Beauty' and 'Nature', for example, are for a large part aesthetical values that increased their weight in post-modern times of relative luxury. In this way, the transition corresponds with the change from exploiting the nature for human use to approaching nature as an independent value that can upgrade civilisation in various ways. The awareness that society depends on large ecosystems of which they are part of made a contribution to the increase of the ecological value. It also resulted in governance approaches that take the characteristics of the ecosystem into account. In addition, it has brought the equal access to consumption of water and the access to mechanisms of influencing the decisions about water systems to the forefront. These values are considered to be responsible for the revival of the water systems in recent times. Although their nature is completely opposite, both in times of 'living with water' and in times of 'fighting the water' the connective capacity of the water systems is large. In both situations water systems connect people and societies via the many positive and negative values that they possess.

Values are a driving factor for changes in water management, but which value(s) will connect in the future, in times of increasing urban population density everywhere? The answer depends mainly on the values that will lead human behaviour. There is a risk for urban societies, where the opportunities to interact with water systems are limited. It could be one of the main factors that determine the paradox of on the one hand the high value that generally is attributed to water and on the other hand the current state of many rivers and lakes. At the same time, the deteriorated state can also accelerate the transition towards sustainability, and again this value prove to be a connector in societal development today as it was during traditional water management practices.

Authors contacts: vanast@fsw.eur.nl,bouma@fsw.eur.nl,bal@fsw.eur.nl

\section{References}

- Agarwal, A., and Narain, S. (2001). Dying Wisdom. Centre for Science and Environment, Delhi: CSE. 
- Agarwal, A., Narain, S., and Khurana, I. (2001). Making Water Everybody's Business, Practice and Policy of Water Harvesting. Centre for Science and Environment, Delhi: CSE.

- Allen, T.F.H., Bandurski B.L., and King A.W. (1992). The ecosystem approach: theory and ecosystem integrity, Washington D.C. (USA): International Joint Commission United States and Canada, Boulder, CO: Westview Press.

- AMC and AUDA. (2005). Jawaharlal Nehru National Urban Renewal Mission: City Development Plan Ahmedabad 2006-2012. Ahmedabad: Ahmedabad Municipal Corporation and Ahmedabad Urban Development Authority.

- Anderies, J. M., Janssen, M. A. and Ostrom, E. (2004). A Framework to Analyze the Robustness of Social-ecological Systems from an Institutional Perspective, Ecology and Society 9 (1): 18.

- Bal, M. (1999). Open spaces in the urban context- lakes as an opportunity. Thesis: Post Graduate Diploma in Urban Design, School of Architecture, CEPT University, Ahmedabad, India.

- Bal, M. (2006). An assessment of the case for increase in public amenity and space. Thesis: MPhil in Planning, Growth and Regeneration, Department of Land Economics, Cambridge University, UK.

- Bansil, P.C. (1991). Water Management in India. New Delhi: Concept Publishing Company.

- Biswas, Asit K. (2004), Integrated Water Resources Management: A Reassessment, Water International, Vol. 29, Issue 2, 2004, pp. 248-256.

- Biswas, Asit K. (2008) Integrated Water Resources Management: Is It Working? in: Water Resources Development, Vol. 24, No. 1, March 2008, pp. 5-22.

- Bouma, J.J., Francois, D., et al. (2009) "Assessing socio-economic impacts of wave overtopping: an institutional perspective", Coastal engineering (2009). Elsevier, 1-6.

- Braungart, M., MacDonough, W., and Bollinger, A. (2007), Cradle-to-cradle design: creating healthy emissions - a strategy for eco-effective product and system design, in: Journal of Cleaner Production (2007) 15, 1337-1348.

- DiMagio, P.J. and Powell, W.W. (1983). 'The Iron cage revisited: institutional isomorphism and collective rationality in organizational fields'. In: American Sociological Review, 48, 147-160.

- Dubbelman, H. (1999). Maatschappelijke golven in de waterbouwkunde, dissertation Delft University of Technology, Delft: Delft University Press,

- Dwivedi, G. (2010). Public-Private Partnerships in Water Sector: Partnerships or Privatisation? Manthan Adhyayan Kendra, Badwani, India

- Euromarket (2003) Water Liberalisation Scenario's. Analysis of the European Unions Explicit and Implicit Policies and Approaches in the larger Water Sector, Euromarket Group, EU: Brussel. Website: http://www.unesco-ihe.org/ProjectActivities/Project-Portfolio/EUROMARKET-Water-Liberalisation-Scenarios

- European Union (2000) Water Framework Directive, Directive 2000/60/EC, Brussel: EU

- Geldof, G.D. (1994). Adaptief waterbeheer: in: Het Waterschap, juni 1994. Deventer: Tauw.

- Hoekstra, A.Y., (2008). Human appropriation of natural capital: A comparison of ecological footprint and water footprint analysis (2008), Journal of Ecological Economics, doi: 10.1016/j.ecolecon.2008.06.021. Elsevier.

- Hooper, B.P. (2005). Integrated River basin Governance, Learning from International experience, London/Seattle: IWM Publishing. 
- ICWE, (1992). International Conference on Water and the Environment, Development Issues for the $21^{\text {st }}$ century, The Dublin Statement Report of the Conference, ICWE Conference January 26-31, 1992, Dublin Ireland, Dublin: ICWE.

- Ministry of Water Management and Infrastructure (1985), Omgaan met Water, naar een integraal waterbeleid, (Dealing with Water, towards an integrated water policy), Den Haag: SDU.

- MoWR (2002). Ministry of Water Resources. National Water Policy. New Delhi: Government of India.

- Narain, V. (2000). India's water crisis: the challenges of Governance, Water Policy 2, pp.433-444.

- Narain, V. (1998). Towards a new Ground Water Institution for India. Water Policy, vol.1, issue 3, pp.357-365.

- North, D.C. (1990). Institutions, institutional change and economic growth. Cambridge: Cambridge University Press.

- Ostrom, E. (1990). Governing the Commons: The Evolution of Institutions for Collective Action. New York: Cambridge University Press.

- Pearce, D.W. and Moran, D. 1994. The economic value of biodiversity. In association with the Biodiversity Programme of IUCN- The World Conservation Union. Earthscan, London.

- Reddy, M.S. and Char, N.V.V. (2006). Management of lakes in India. Lakes \& Reservoirs: Research and Management 2006 11: 227-237.

- Saeijs, H.L.F. (1995). Levend water en een Wereldstad, ecologie als economische factor in het waterbeheer, oratie Erasmus Universiteit Rotterdam, Rotterdam: Erasmus Studiecentrum voor Milieukunde.

- Schuijt, K. (2003). Valuation of Water: the process of economic valuation of ecosystems in water management, $\mathrm{PhD}$ dissertation, Erasmus University Rotterdam.

- Teclaf, Ludwik A. (1996), Evolution of the River Basin Concept in International Water Law, Natural Resources Journal, Vol. 36, Spring 1996, No 2.

- UN (1987), United Nations, Register of international rivers and lake basins, (Department of Economic and Social Affairs) in: Water and Supply Management, Vol. 2, NO 1. pp. 1-58.

- UNCED (United Nations Conference on Environment and Development), Agenda 21, Declaration of Rio de Janeiro, New York: UN.

- Valkering P. and A. Offermans (2008). Inspelen op verandering: naar een robuuste en flexible strategie voor waterbeheer. Eindrapportage van de pilotstudie Perspectieven in Integraal Waterbeheer, Maastricht: International Centre for Integrated assessment and Sustainable development.

- Van Ast, J.A., (1998). Trends Towards Interactive Water Management; Developments in International River Basin Management, in: Physics and Chemistry of the Earth (B), Vol. 24, No 6, Elsevier Science, Oxford, blz 597-602; 1999.

- Van Ast, J.A., (2000). Interactief watermanagement in grensoverschrijdende riviersystemen (Interactive water management in transboundary river systems), Delft: Eburon.

- Van der Brugge, R. and Rotmans, J. (2010). Towards Transition Management of European Water Resources, Journal Water Resource Management, 2010

- van der Veeren,, R. and R van Cleef (2008). Ervaringen met MKBA in het natuuren milieubeleid, Tijdschrift H20/17, pp.17-19.

- Van Rooy, P.T.J.C., van Sluis J.W., Tolkamp H.H., de Jong J. (1997) Op weg naar totaal waterbeheer (7) AUTUNNO. In: H2O, 11 (30) 1997:348-355... 
- Van Schie, N. and Bouma, J.J. (2008). The Concept of Covaluation: institutionalisation the involvement of local (public) values in regional planning on water. Competition and Regulation in Network Industries, Volume 9(2008), No.4.: 361-392 Intersentia

- WCED, (1987). World Commission on Environment and Development, Our Common Future, Oxford (UK): Oxford University Press.

- Williamson, O.E (1998). Transaction costs economics: how it works, where is it headed, The Economist, Vol. 146, No.1, pp.23-58

- Williamson, O.E. (1979). Transaction costs economics: the governance of contractual relations, Journal of Law and Economics, 22 October, pp. 3-61.

- World Bank, (1998). India. Water Resources Management Sector Review: Report on inter-sectoral water allocation, planning and management, New York: UN. 


\section{Appendix: Abstract}

Water systems such as rivers and lakes have always had different social, ecological and economical values at different spatial and temporal scales of societal developments. The priority on the different values projected by the society as well as the water managers have had a bearing on the water governance approach in the traditional as well as in the modern water management practices. The multiple sectors dealing with water governance is an outcome of the demand for different values by society and the water managers. The interlinking and overlapping values of the water systems at the spatial and temporal scales have determined a connective capacity in the water governance, be it the coordination between the values or the competition between the values. The water systems are proving to be the connectors in the societal development today as they were in the old and traditional water management practices. Still there is a limited understanding of how the water systems across diverse sectors are linked to the changing social systems at spatial and temporal scales. In this chapter, the expected and realized values of water system in the Netherlands and India are discussed with reference to lake systems in Tilburg and in Ahmedabad. The chapter concludes with the findings that values generated by lakes systems drive the water governance approach of the lakes and those values change in societies with time. 